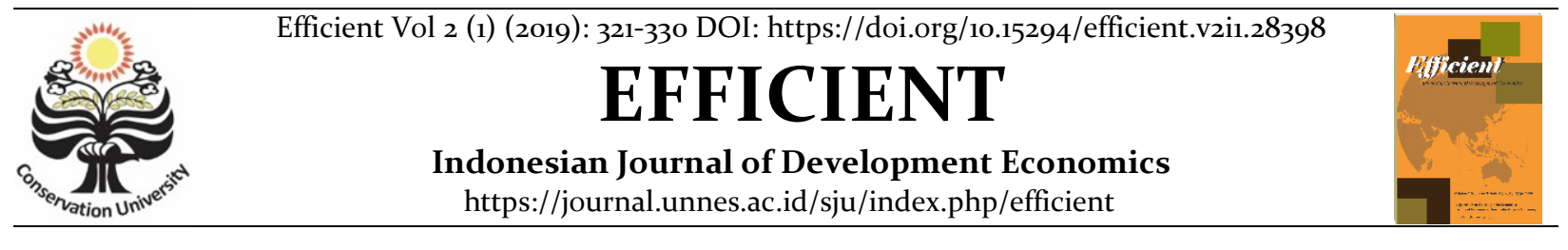

\title{
Analysis of Factors Affecting Integrated Public Service Performance
}

\author{
Humairoh Hudiyatul Hanifah ${ }^{\bowtie}$ \\ Jurusan Ekonomi Pembangunan, Fakultas Ekonomi, Universitas Negeri Semarang \\ Permalink/DOI: https://doi.org/10.15294/efficient.v2i1.28398 \\ Received: July 2018 ; Accepted: October 2018 ; Published: January 2019
}

\begin{abstract}
The purpose of this study is to analyze the influence of competence, motivation, and work environment of employees on the performance of public service Department of Investment and One Stop Service (DPM-PTSP) Semarang City. The research method used in this research is quantitative research method with sampling technique Quota Sampling and Judgment Sampling. Processing techniques and data analysis used are test validity, reliability test, classical assumption test, multiple linear regression analysis, and hypothesis test. The result of the research shows that employee competency, employee motivation, and work environment have positive and significant influence on the performance of public service at One Stop Service and One Stop Service (DPM-PTSP) Semarang City based on the indicators that have been determined in the research. However, there are still some unsuitable indicators, such as employees who need time to adapt to the latest rules, policies, technologies and systems, the need for additional facilities, simplification of licensing compliance requirements and submission process, provision of information on changes in the requirements of the completeness of the licenses and the submission process through the official web of the One Stop Service and One Stop Service (DPM-PTSP) of Semarang City or attached to the licensing application form.
\end{abstract}

Keywords: Public Service, Performance, Semarang City

\begin{abstract}
Abstrak
Tujuan penelitian ini adalah menganalisis pengaruh kompetensi, motivasi, dan lingkungan kerja pegawai terhadap kinerja pelayanan publik Dinas Penanaman Modal dan Pelayanan Terpadu Satu Pintu (DPM-PTSP) Kota Semarang. Metode penelitian yang digunakan dalam penelitian ini adalah metode penelitian kuantitatif dengan teknik pengambilan sampel Quota Sampling dan Judgement Sampling. Teknik pengolahan dan analisis data yang digunakan adalah uji validitas, uji reliabilitas, uji asumsi klasik, analisis regresi linier berganda, dan uji hipotesis. Hasil penelitian menunjukkan kompetensi pegawai, motivasi pegawai, dan lingkungan kerja pegawai memiliki pengaruh yang positif dan signifikan terhadap kinerja pelayanan publik di Dinas Penanaman Modal dan Pelayanan Terpadu Satu Pintu (DPM-PTSP) Kota Semarang berdasarkan indikator-indikator yang telah ditetapkan dalam penelitian. Namun masih ada beberapa indikator yang belum sesuai, seperti pegawai yang membutuhkan waktu untuk menyesuaikan diri dengan aturan, kebijakan, teknologi, dan sistem terbaru, lalu perlunya penambahan fasilitas, penyederhanaan persyaratan kelengkapan perizinan dan proses pengajuan, pemberian informasi perubahan persyaratan kelengkapan perizinan dan proses pengajuan melalui web resmi Dinas Penanaman Modal dan Pelayanan Terpadu Satu Pintu (DPM-PTSP) Kota Semarang atau terlampir pada form pengajuan perizinan.
\end{abstract}

\section{Kata Kunci: Layanan Publik, Kekuatan, Kota Semarang}

How to Cite: Hanifah, H. (2019). Analysis of Factors Affecting Integrated Public Service Performance. EFFICIENT Indonesian Journal of Development Economics, 2(1), 321-330. https://doi.org/10.15294/efficient.v2i1.28398

(C) 2019 Semarang State University. All rights reserved

\footnotetext{
Alamat Korespondensi :

Alamat: Gedung L2 Lantai 2 FE Unnes

Kampus Sekaran, Gunungpati, Semarang, 50229

E-mail : humairoh.hh@gmail.com
}

ISSN 2655-6197 


\section{INTRODUCTION}

Indonesia as one of the developing countries continues to increase its economic growth through various ways (Mahardiki \& Santoso, 2013). One of them is the increasingly critical society wants a professional government, especially in the implementation of quality public services (Hassan, 2015). Public services provided by the government, certainly not escape from how government employees provide the best service to the community through their best performance (Prakoso, 2015).

Since the enactment of regional autonomy, public services are not only done by the central government, but also the local government. Basically public service is the responsibility of local government in order to meet the basic needs of society and to improve the welfare of society (Mouw, 2013). The existence of this regional autonomy policy, it is expected that local governments can better understand the wishes of the community so that in the provision of services more in line with community demand (Lufunyo, 2013). However, public services provided by the central and local governments are still getting a lot of complaints from the community that accommodated and followed up by the Ombudsman RI.

In 2017 based on the report of Ombudsman RI Representative of Central Java, Semarang City occupies the first position in Central Java as the most widely complained area with the number of complaints as many as 87 complaints. In the second and third positions occupied by Pati and Kendal (Ombudsman RI). It also mentioned several offices reported to the Ombudsman RI Representative of Central Java, one of the
Office of Investment and One Stop Service (DPM-PTSP) Semarang City and the office responsive to complaints only the Department of Education and Health Office of Semarang, the rest less responsive (Ombudsman RI).

Semarang City Government in order to help accelerate the realization of good government, improve public service quality by making licensing policy is "one door" by forming One Stop Service and One Stop Service (DPM-PTSP) Semarang City based on Presidential Decree Number 97 Year 2014 However, in the journey, the performance of the DPM-PTSP employees of Semarang City is still not as expected. Whereas the public satisfaction of the services provided, it can be used as a benchmark and implicate the success of an organization (Ningsih, 2015).

In 2013 until 2017 most of the licensing applications have not been resolved maximally. There are still many licenses that have not been able to comply with the Minimum Service Standards (SPM), ie permissions that can be completed in accordance with predefined time standards. Most of them do not conform to or exceed the prescribed time standard, even licensing with a percentage of its SPM of zero percent or since registering that year, until the end of licensing is still in process.

Factors that affect the performance of employees in doing their work vary. Research conducted by Mr. \& Thao (2017) in Vietnam, charismatic leadership can also impact on the perceptions and judgments of employees, thus triggering the behavior of failure improvement in public services. In addition, charismatic leaders have an effective impact on the catalysis of Public Service Recovery Performance (PSRP) because they can attract 
employees to change their vision and mission of public service which is one of motivation in doing public service. In addition, research conducted by Palma, Hinna, and Mangia (2017) shows the result that Public Service Motivation (PSM) is an important driver for productivity. But user orientation becomes a stronger lever than Public Service Motivation (PSM).

Table 1. Licensing DPM-PTSP Semarang City Appropriate Minimum Service Standard

\begin{tabular}{|c|c|c|c|c|c|}
\hline \multirow{2}{*}{ Licensing Type } & \multicolumn{5}{|c|}{ Year } \\
\hline & 2013 & 2014 & 2015 & 2016 & 2017 \\
\hline Advertising Point Permission & $4,52 \%$ & $3,06 \%$ & $6,87 \%$ & $2,98 \%$ & $72,02 \%$ \\
\hline Permanent Billing Install Permission & $5,14 \%$ & $4,15 \%$ & $7,22 \%$ & $18,87 \%$ & $90,10 \%$ \\
\hline Primary Clinical Permission & $83,33 \%$ & $84,91 \%$ & $96,00 \%$ & $73,77 \%$ & $55,26 \%$ \\
\hline Business license & $94,90 \%$ & $93,40 \%$ & $97,22 \%$ & $99,37 \%$ & $37,76 \%$ \\
\hline Industrial Register Sign & o\% & o\% & $12,50 \%$ & $6,25 \%$ & o\% \\
\hline Certificate of Company Registration & $\mathrm{o} \%$ & $27,25 \%$ & $71,92 \%$ & $91,13 \%$ & $15,91 \%$ \\
\hline Building Permit & $60,70 \%$ & $79,11 \%$ & $58,79 \%$ & $90,60 \%$ & $69,23 \%$ \\
\hline Disturbance License & $30,56 \%$ & $20,28 \%$ & $17,63 \%$ & $39,97 \%$ & $34,11 \%$ \\
\hline Construction Service Business License & o\% & o\% & o\% & o\% & o\% \\
\hline
\end{tabular}

Source: DPM-PTSP Semarang City (Data processed) (2017).

As one of the public service agencies, not yet the maximum service in completing licensing in accordance with the SPM indicates an indication of the low performance of the DPM-PTSP Kota Semarang. In connection with this, the performance of the DPM-PTSP employees of Kota Semarang need to be researched and immediately addressed in order to provide better service to the community.

\section{RESEARCH METHODS}

The research method used is quantitative research method. The type of data used is primary and secondary data. Primary data in the form of questionnaires and interviews. While secondary data in this research is data from Ombudsman RI, Department of Investment and One Stop Integrated Service (DPM-PTSP) Semarang City, books, journals, and others. In this study used nonprobability sample design which has major differences with probability samples ie nonprobability samples chosen arbitrarily by the researchers or in other words, the probability of each member of the population is unknown (Kuncoro, 2013). Sampling technique in this research is Quota Sampling and Judgment Sampling. Dependent variable or dependent variabel in this research is employee 
performance (Y). Furthermore, independent variables or independent variables in this study include employee competence (X1), employee work motivation $\left(\mathrm{X}_{2}\right)$, and work environment $\left(\mathrm{X}_{3}\right)$.

The framework of thinking that became the reference in this research, namely "Suspected of the influence between competence, motivation, and the work environment of employees on the performance of public services". Data collection techniques used include interviews, questionnaires or questionnaires, and observation. While the technique of processing and data analysis used in this research is multiple linear regression analysis, classical assumption test, and hypothesis test using Eviews 9. In addition, in this research also tested the validity and reliability test instrument using SPSS 20.

Multiple linear regression equation used in this research as follows.

Kin $=\alpha+\beta_{1} K p+\beta_{2} M p+\beta_{3} L p+\varepsilon \ldots \ldots(1)$

Information :

$\begin{aligned} \text { Kin }= & \text { Employee Performance } \\ \mathrm{A}= & \text { Coefficient of Constants } \\ \beta_{1}= & \text { Employee Competency Regression } \\ & \text { Coefficient } \\ \beta_{2}= & \text { Coefficient of Employee } \\ & \text { Motivation Regression } \\ \beta_{3}= & \text { Regression Coefficient Working } \\ & \text { Employee Environment } \\ \mathrm{Kp}= & \text { Employee Competencies } \\ \mathrm{Mp}= & \text { Employee Motivation } \\ \mathrm{Lp}= & \text { Working Employee Environment } \\ \mathrm{E}= & \text { Interference Variables }\end{aligned}$

\section{RESULTS AND DISCUSSION}

The first data was collected by taking 15 respondents, to test the validity and reliability test on the questionnaire. All statements are declared valid because the validity coefficient is greater than $\mathrm{r}$-critical 0.3061 . Testing reliability in this study using Cronbach's Alpha method. Cronbach's Alpha value of each of each variable is greater than r-critical 0.600 so it can be concluded that the statement on the reliable research questionnaire to measure the variable.

A good regression model if it has data that has or is close to a normal distribution. In conducting the normality test, the Jarque-Bera probability test is used by comparing the Jarque-Bera probability value with the alpha level of $0.05 \quad(5 \%)$. If the Jarque-Bera probability value is greater than 0.05 then it can be concluded that the residual is normally distributed and vice versa, if the value is smaller then it can be concluded that the residual is not normally distributed.

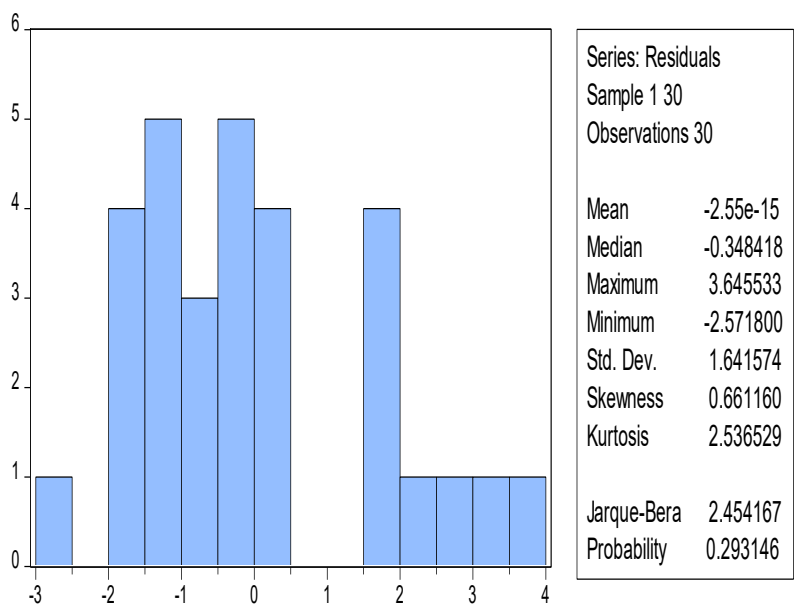

Figure 1. Normality Test Results Source: Data processed Eviews 9 (2018) 
Based on normality test result in figure 1 , Jarque-Bera probability value counted $2,454,167$. The Jarque-Bera probability value is greater than 0.05 , so it can be concluded that the residual is normally distributed, which means the classical assumption of normality is fulfilled.

Multicollinearity test is used to determine whether inter independent variables are related or not. This multicolinearity test is done by looking at the VIF value of each independent variable. If the VIF value $<10$ then it can be concluded that the data is free from symptoms of multicollinearity (Ghozali, 2009).

Table 2. Multicollinearity Test Results

\begin{tabular}{lc}
\hline Variabel & VIF \\
\hline Competence $\left(\mathrm{X}_{1}\right)$ & 2.600270 \\
Motivation $\left(\mathrm{X}_{2}\right)$ & 3.163990 \\
Work Environment $\left(\mathrm{X}_{3}\right)$ & 4.118633 \\
\hline
\end{tabular}

Sumber: Olah Data Eviews 9 (2017)

Based on the multicollinearity test results in table 2, the VIF value of each independent variable in the Centered VIF column is less than 10. Then it can be concluded that the data is free from symptoms of multicolinearity. A good regression model is a model of homoscedasticity or no heteroscedasticity. If $\mathrm{p}$ value $>0,05$ is not significant it does not mean heteroscedasticity, and this means the regression model passed the heteroscedasticity test (Ghozali, 2009). Based on the results of heteroskedastisita test Prob value. Chi-Square (3) of 0.6917 greater than 0.05 indicates that the regression model is free from heteroscedasticity.
Based on the result of heteroscedasticity test in table 3, Prob value. Chi-Square (3) is o.6917. Prob value. Chi-Square (3) greater than 0.05 indicates that the regression model is free from heteroscedasticity.

Table 3. Heteroscedasticity Test Results

\begin{tabular}{|c|c|c|c|}
\hline F-statistic & 0.443094 & $\begin{array}{ll}\text { Prob. } & \text { F } \\
(3,26) & \end{array}$ & 0.7242 \\
\hline $\mathrm{Obs}^{*} \mathrm{R}-$ & & Prob. Chi- & \\
\hline squared & 1.459184 & Square(3) & 0.6917 \\
\hline \multicolumn{4}{|l|}{ Scaled } \\
\hline explained & & Prob. Chi- & \\
\hline SS & 0.842025 & Square(3) & 0.8394 \\
\hline
\end{tabular}

Source: Data processed Eviews 9 (2018)

The autocorrelation test aims to test whether in the linear regression model there is a correlation between the confounding error in period $t$ with the intruder error in period $t-1$ (previous). This test uses the LM (BreuschGodfrey) test.

Table 4. Autocorrelation Test Results

\begin{tabular}{llll}
\hline F- & & Prob. & \\
statistic & 1.051497 & $\mathrm{~F}(2,24)$ & 0.3650 \\
\hline & & Prob. & \\
& & Chi- & \\
& & & \\
Obs*R- & 2.416957 & Square & \\
squared & & $(2)$ & \\
\hline
\end{tabular}

Source: Data processed Eviews 9 (2018)

Prob value. F (2.24) or can also be called the probability value $\mathrm{F}$ arithmetic based on the results of autocorrelation test in table 4 shows the value of 0.3650 . The value is greater than the alpha level of $0.05(5 \%)$ so there is no autocorrelation.

F statistic test is used to know the effect of independent variable that is employee 
competence, employee motivation, and work environment of employees together to dependent variable, employee performance. $\mathrm{F}$ test results indicate that the independent variables used in the study affect together to the dependent variable. This can be known by comparison of Prob (F-statistic) value of o.oooooo which is smaller than alpha value $0.05(5 \%)$. The $\mathrm{t}$ test in multiple linear regression aims to test whether the regression coefficients and constants expected to estimate multiple linear regression models are appropriate or not. If Prob value. t-statistic smaller than alpha $0.05(5 \%)$ it can be concluded that the independent variables significantly influence the dependent variable, and vice versa.

Prob value. t-statistic of employee competency variable equal to 0.0019 is smaller than 0.05 , it can be concluded that employee competency variable significantly influence employee performance variable at alpha 0.05 (5\%). Next, Prob value. t-statistic of employee motivation variable equal to 0,0133 smaller than 0.05 , hence can be concluded that employee motivation variable have significant effect to employee performance variable at alpha 5\%. Then Prob value. t-statistic of work environment variable employee equal to o,0215 smaller than 0.05 , indicate that employee motivation variable have significant effect to employee performance variable at alpha $5 \% .1$

Based on the results of multiple linear regression analysis, it can be seen that the coefficient of determination (R-squared) obtained is 0.882924 . This figure shows that employee competency variable, employee motivation, and work environment can explain $88.29 \%$ of employee performance variable at One Stop Service and One Stop Service (DPM-
PTSP) Semarang City, while the remaining $11.71 \%$ can be explained by other variables not found in the analysis model in this study.

In Table 5. the calculation of multiple linear regression analysis shows the effect of independent variable to the dependent variable which can be seen on the coefficient of determination (R-squared) that is equal to 0.882924 which shows that the influence of employee competence, employee motivation, and work environment together have a significant influence on the performance of employees of the One Stop Service (DPMPTSP) of Semarang City is $88.29 \%$ while the rest of $11.71 \%$ is explained by other variables not included in this study.

Based on the results of calculation of multiple linear regression analysis in table 5 , it can be concluded that the probability value significantly employee competence variable that is o.0o19 smaller than the value of $\alpha=5 \%$ ( $0.0019<0.05)$ and positive sign, this indicates that employee competency variable has a positive and significant effect on employee performance variables. Can be drawn also the conclusion that employee competency variable have a positive and significant effect to employee performance variable.The significant probability value of work motivation variable is 0.0133 which is smaller than the value of $\alpha=$ $5 \%(0.01335<0.05)$ and is positive signified which means work motivation variable has positive and significant influence to employee performance variable. Based on these results, it can be concluded that the variable of work motivation have positive and significant effect to employee performance variable. The significant probability value of work environment variable is 0,0215 smaller than the value of $\alpha=5 \%(0.0215<0.05)$ and signified 
positive which means work environment that the work environment variables variable has positive and significant influence have a positive and significant effect on to employee performance variable. Based employee performance variable. on these results, it can be concluded

Table 5. Regression Results

\begin{tabular}{llll}
\hline Variabel & Koefisien & t-Statistic & Probabilitas \\
\hline Competence $\left(\mathrm{X}_{1}\right)$ & 0,464166 & 3,448775 & 0,0019 \\
Motivation $\left(\mathrm{X}_{2}\right)$ & 0,465987 & 2,656067 & 0,0133 \\
Work Environment $\left(\mathrm{X}_{3}\right)$ & $0,64268 \mathrm{o}$ & 2,447019 & 0,0215 \\
R-squared & & & 0,882924 \\
Adjusted R-squared & & 0,869415 \\
$\quad$ F-statistic & & & 65,35939 \\
Prob(F-statistic) & & 0,000000 \\
\hline
\end{tabular}

Source: Data processed Eviews 9 (2018).

Based on the results of the study, employee competence variables indicate that these variables have a positive and significant effect on employee performance variables. The higher the competency possessed by the employee, the higher the performance of the employee. With high competence, employees can complete tasks that are given more quickly, precisely, and efficiently, so that the task can be completed immediately. Completion of tasks quickly and precisely produces good performance output for both the individual employee and the organization.

Analysis on the results of the questionnaire consisting of indicators of knowledge, experience, skills and attitudes shows that employees already have the knowledge, experience, and skills that qualify in their respective fields of work, although sometimes changes in policies or regulations require employees to quickly adjust and employee skills on the latest technology or system sometimes takes time to learn it. The attitude of employees in working and serving service users is good and good by serving service users with friendly, courteous, polite, giving clear explanation, and non - discriminatory attitude. This is in accordance with previous research conducted Octorano (2015) that competence affects the performance of employees. The higher the level of competence then the performance will increase and research ever undertaken by Mohklas (2015) also supports the results of this study. The competencies possessed by employees give a considerable effect on employee performance. Increased competence is done through education and training held by offices and other institutions. In addition, this is also in line with what Siagian (1992) has argued that competence is a set of specific behaviors, education, skills and knowledge that are the key and key elements for effective and efficient leadership. 
Based on the results of the study, employee motivation variable shows that the variable has a positive and significant effect on employee performance variable. Motivation becomes a variable that plays a dominant role because it is an encouragement from within the employee to achieve the desired goal, especially related to the welfare of life to be achieved through working properly, so that his expectations with the employee issued the best performance will achieve the goals he expected especially in the welfare of life.

Analysis on the results of the questionnaire consisting of indicators of future guarantee fulfillment, rewards (rewards) on job performance, and the desire to obtain recognition of the work results show that employees have felt the policies and policies of the leadership with the fulfillment of these three indicators. An example is the guarantee of promotion in accordance with the time as the fulfillment of future guarantees, the appreciation of the work performance as a form of reward (reward) to the performance of work, then supervisors who appreciate the work as a form of recognition of the work of employees.

This is also in accordance with what was disclosed by Winardi (2000), motivation is a desire that exists within an individual that provides stimulation to perform an action. Furthermore, in the research conducted by Mohklas (2015), Sidanti (2015), Cheng (2015), Tilekson (2016) and Surahman (2017) also supported the results of the study. Motivation has a considerable influence in the employee to produce the best performance output from the employee. Intrinsic and extrinsic work motivation, such as expectations to be achieved, benefits, incentives, and policies issued by the leadership can have a positive and significant effect on employee performance.

Based on the results of research, work environment variable employee indicates that the variable has a positive and significant effect on employee performance variable. The higher the quality of work environment perceived by employees, the higher the performance of the employee. The quality of a good working environment supports a good employee working atmosphere so as to create maximum employee performance output. Uncomfortable work environment, not in accordance with the needs and standards set causing employees uncomfortable and unable to provide the best performance, as well as perceived by service users, if the environment around the service area does not provide comfort, service users also become uncomfortable and less satisfied with the services provided.

Analysis on the results of the questionnaire consisting of indicators of physical environment and non physical environment shows the result that employees are quite satisfied with the state of the working environment. What makes employees less satisfied with their work environment is the physical environment. Employees feel that the workspace, especially in the service area, requires additional Air Conditioner (AC) because they feel the service room is quite hot so it is less convenient for employees and users of the service, besides the lack of trash and the absence of queue line also felt less comfortable by service users. The results of this study in accordance with the theory put forward by Nitisemito (2006) that the work environment is everything that is around the employees, which can give effect to him in carrying out 
the tasks charged. In line with Nitisemito (2006), Mangkunegara (2009) also argues that the work environment is all aspects of physical work, psychological work, and work regulations that can affect in job satisfaction and achievement of productivity. In addition, previous research conducted by Sidanti (2015) and Wijaya (2017) found that the work environment had a positive effect on employee performance and the changes that occurred in the smallest work environment had a significant impact or influence on employee performance. So based on the theory and research that has been submitted can be concluded that the work environment has an important role in supporting employee performance in order to maximize service users with good service and service users were satisfied and comfortable with the services provided.

\section{CONCLUSION}

Based on the description of research results and discussion, the following conclusions can be drawn. The performance of public service at One Stop Service (DPMPTSP) of Semarang City can be assessed through three things, namely employee competency, employee motivation, and work environment of employees who have positive and significant influence on employee performance.

Employee competence shows the result that employees already have the knowledge, experience, and skills that are qualified in their respective fields of work, although employees must quickly adapt to the latest changes in rules, policies, technologies or systems. Attitude of employees in working and serving the user service is good and good. Employee motivation results show that employees already feel that the three indicators have been met through policies and policies issued by the leadership or superiors. The work environment of the employees shows that employees are quite satisfied with their working environment. What makes employees less satisfied with their work environment is the physical environment. Employees and service users feel the need for additional facilities.

\section{REFERENCES}

Cheng, K.-T. (2015). Public Service Motivation And Job Performance In Public Utilities: An Investigation In A Taiwan Sample. International Journal of Public Sector Management, 28(4/5), 352-370.

Ghozali, I. (2009). Aplikasi Analisis Multivariate dengan Program SPSS Edisi Keempat. Semarang: Universitas Diponegoro.

Hassan, M. S. (2015). Ensuring Effective Public Service Delivery in the Field Administration of Bangladesh to Boast up Good Governance: The Perspective of Deputy Commissioner Office. International Journal of Business and Management, 10(4), 92-112.

Kuncoro, M. (2013). Metode Riset untuk Bisnis \& Ekonomi. Jakarta: Penerbit Erlangga.

Lufunyo, H. (2013). Impact of Public Sector Reforms on Service Delivery in Tanzania. International Journal of Social Science Tomorrow, 2(2), 1-26.

Mahardiki, D., \& Santoso, R. P. (2013). Analisis Perubahan Ketimpangan Pendapatan Dan Pertumbuhan Ekonomi Antar Propinsi Di Indonesia 2006-2011. JEJAK: Jurnal Ekonomi Dan Kebijakan, 6(1), 179193.

Mangkunegara, A. P. (2009). Manajemen Sumber Daya Manusia. Bandung: PT. Remaja Rosdakarya.

Mohklas. (2015). Pengaruh Kompetensi Dan Motivasi Terhadap Kinerja Pegawai Dengan Komunikasi Sebagai Variabel Moderating (Studi Pada Kecamatan Gayamsari Kota Semarang). Fokus Ekonomi, 10(2), 99-119.

Mouw, E. (2013). Kualitas Pelayanan Publik di Daerah. Jurnal UNIERA, 2(2), 92-103. 
Ningsih, A. A. (2015). Kinerja Aparatur dalam Meningkatkan Pelayanan Publik Pada Kantor Kelurahan Nunukan Tengah Kabupaten Nunukan. eJournal Ilmu Administrasi Negara, 3(4), 12951306.

Nitisemito, A. S. (2006). Manajemen Personalia. Jakarta: Ghalia Indonesia.

Octorano, D. F. (2015). Pengaruh Koordinasi, Kompetensi dan Disiplin Terhadap Kinerja Pegawai Unit Layanan Pengadaan Kementerian Agama Pusat (ULP Kemenag Pusat). Jurnal MIX, 5(1), 108-123.

Prakoso, S. B. (2015). Efektivitas Pelayanan Kesehatan BPJS di PUSKESMAS Kecamatan Batang. Economics Development Analysis Journal (EDAJ) $4(1), 73-81$.

Siagian, S. (2005). Administrasi Pembangunan, Konsep Dimensi dan Strateginya. Jakarta: Bumi Aksara.

Sidanti, H. (2015). Pengaruh Lingkungan Kerja, Disiplin Kerja dan Motivasi Kerja Terhadap Kinerja
Pegawai Negeri Sipil di Sekretariat DPRD Kabupaten Madiun. Jurnal JIBEKA, 9(1), 44-53.

Surahman, D. (2017). Pengaruh Kepemimpinan dan Motivasi Kerja Pegawai Terhadap Kinerja Pegawai dalam Mewujudkan Efektivitas Pelaksanaan Program Kerja. Jurnal Publik, 11(2), 257-268.

Tilekson. (2016). Analisis Pengaruh Gaya Kepemimpinan Dan Motivasi Kerja Terhadap Kinerja Pegawai Unit Pelaksana Teknis Dinas Pendidikan Kecamatan Raren Batuah Kabupaten Barito Timur. Jurnal Ilmiah Ekonomi Bisnis, 2(3), 427441.

Tuan, L. T., \& Thao, V. T. (2017). Charismatic leadership and public service recovery performance. Marketing Intelligence \& Planning.

Wijaya, H. (2017). Pengaruh Lingkungan Kerja Terhadap Kinerja Pegawai Pada Instansi Pemerintah Daerah Kabupaten Musi Banyuasin (Studi Kasus Dinas Pertambangan dan Energi Kabupaten Musi Banyuasin). Jurnal Ecoment Global, 2(1), 40-50. 